\title{
Peranan Manajemen Berbasis Sekolah (MBS)
}

\author{
${ }^{1}$ Maman Mulya Karnama, ${ }^{2}$ Depi Prihamdani \\ ${ }^{1}$ Managemen, FEB Universitas Buana Perjuangan, INDONESIA \\ ${ }^{2}$ Pendidikan Guru Sekolah Dasar (PGSD), FKIP Universitas Buana Perjuangan, INDONESIA \\ e-mail: ${ }^{1}$ maman.mulya@ubpkarawang.ac.id, ${ }^{2}$ depi.prihamdani@ubpkarawang.ac.id
}

\section{Role of School-Based Management (MBS)}

\begin{tabular}{|c|c|}
\hline Kata Kunci & Abstrak \\
\hline $\begin{array}{l}\text { Manajemen Berbasis } \\
\text { sekolah, Otonomi }\end{array}$ & $\begin{array}{l}\text { Perkembangan Ilmu dan Teknologi telah berdampak pada perubahan } \\
\text { besar yang terjadi pada dunia pendidikan. Salah satu perubahan } \\
\text { mendasar pada dunia pendidikan adalah pada tingkatan manajemen, } \\
\text { yaitu dari manajemen berbasis pusat menjadi manajemen berbasis } \\
\text { daerah. Metode yang digunakan pada tulisan ini adalah hanya } \\
\text { berdasarkan tinjauan pustaka/literatur, maka untuk mengetahui } \\
\text { peranan dari pelaksanaan pelaksanaan MBS terhadap proses belajar } \\
\text { mengajar di sekolah, akan dikaji dan diulas berdasarkan fakta dan } \\
\text { pendapat dari para pakar yang berkompeten dalam bidang pendidikan. }\end{array}$ \\
\hline
\end{tabular}

Keywords:

School-based

Management, Autonomy

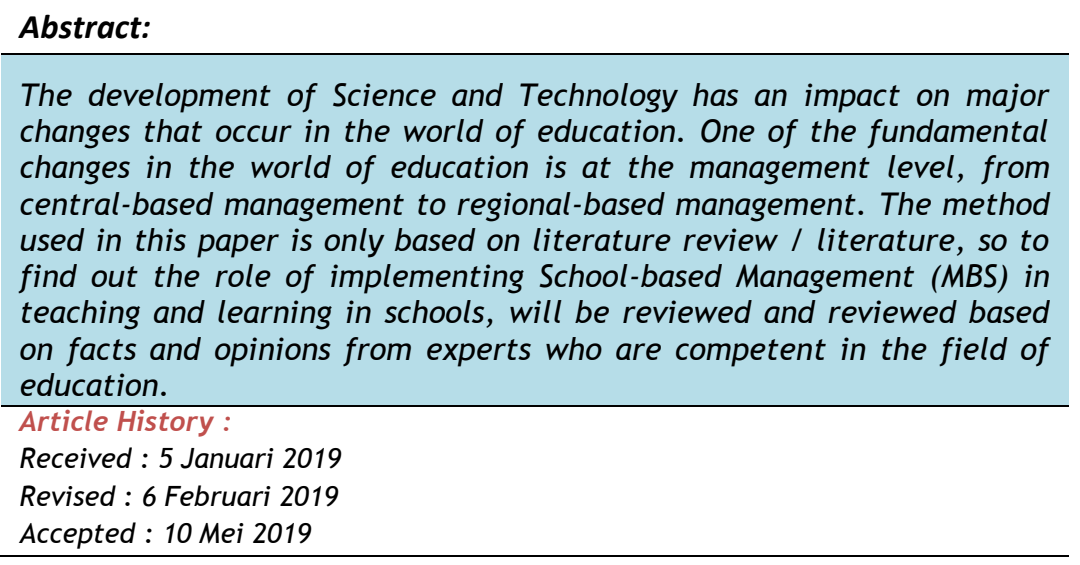

\section{PENDAHULUAN}

Undang-Undang Republik Indonesia Nomor 22 Tahun 1999 yang disempurnakan dengan Undang-Undang RI Nomor 32 Tahun 2004 tentang Pemerintah Daerah dan Undang-Undang RI Nomor 33 Tahun 2004 tentang Perimbangan Keuangan Antara Pemerintah Pusat dan Pemerintah Daerah. UU tersebut berdampak kepada pendidikan yang diselenggarakan di Negara kita, konsekuensi dari kedua Undang-Undang tersebut pada bidang pendidikan mengindikasikan bahwa manajemen pendidikan harus disesuaikan dengan jiwa dan semangat otonomi. Karena itu, manajemen pendidikan berbasis pusat diubah menjadi manajemen berbasis sekolah (MBS).

Manajemen dapat diartikan sebagai sebuah pengelolaan (Asmara \& Ardiyanti, 2019), maka dengan demikian MBS dapat diartikan (Syamsuddin (Dolong, 2018) salah satu alternatif pengelolaan sekolah dalam kerangka desentralisasi dalam bidang pendidikan yang 
memungkinkan adanya otonomi yang luas di tingkat sekolah. MBS pada prinsipnya bertumpu pada sekolah dan masyarakat serta jauh dari birokrasi yang sentralistik. MBS berpotensi untuk meningkatkan partisipasi masyarakat, pemerataan, efisiensi, serta manajemen yang bertumpu pada tingkat sekolah.

Melalui MBS, kewenangan dalam pengelolaan sekolah bertumpu pada sekolah dan stakeholder harus terkait langsung. Dengan demikian manajemen sekolah lebih terbuka dan diharapkan lebih optimal, menghindarkan format sentralisasi dan birokratisasi yang dapat menyebabkan hilangnya fungsi manajemen sekolah. MBS juga didasarkan pada kenyataan bahwa setiap sekolah, layaknya setiap individu, memiliki keunikannya sendiri. Setiap sekolah memiliki karakteristik yang tidak dimiliki sekolah lain. Setiap sekolah memiliki karakteristik dan kondisi lokal yang berbeda satu dengan yang lain. Oleh karena itu, untuk optimalnya proses pendidikan di tiap sekolah, maka sekolah perlu mengelola sekolah sesuai karakteristik dan kondisi lokal tersebut. Pada intinya tujuan MBS adalah menciptakan mutu pendidikan yang lebih baik, lebih bermutu, efektif dan efisisen (depdikbud, 2018). Berdasarkan pernyataan di atas maka, penulis sangat tertarik untuk melihat peranan MBS yang diterapkan dan sejauh mana peran MBS untuk bisa berhasil membawa sekolah menjadi sekolah unggul, efektif dan efisien.

\section{Metode Penelitian}

Tulisan ini menggunakan metode tinjauan pustaka, yang mencoba mengungkap peranan Manaejmen Berbasis Sekolah (MBS) pada sekolah-sekolah di Indonesia. Untuk melihat peranan dan fakta-fakta di lapangan mengenai MBS, penulis mencoba mengkaji dari berbagai sumber untuk mengetahui lebih jauh tentang bagaimana MBS berlangsung di persekolahan.

\section{PEMBAHASAN}

Untuk bisa melihat peranan dari seberapa efektifnya peran MBS, maka perlu diperhatikan beberapaha hal terkait dengan MBS, diantaranya:

\section{Pengertian Manajemen Berbasis Sekolah (MBS)}

Kata manajemen berasal dari bahasa inggris, yaitu dari kata to manage yang artinya pengurus, mengatur melaksanakan, dan mengelola. (Mutohar, 2016:34). Atau bisa juga diartikan bahwa istilah manajemen sama artinya dengan administrasi (Sutisna, 1983), Maka Rifai (1982) menyebutkan bahwa administrasi adalah keseluruhan proses yang mempergunakan dan mengikutsertakan semua sumber potensi yang tersedia dan yang sesuai, baik personal maupun material, dalam usaha mencapai bersama suatu tujuan secara efektif dan efisien (Asmara \& Ardiyanti, 2019).

Manajemen Berbasis Sekolah (MBS) atau (school-based manajemen). Secara garis besar, manajemen berbasis sekolah merupakan manajemen yang memberikan otonomi atau tanggung jawab lebih besar kepada sekolah dan mendorong partisipasi dan dukungan secara langsung warga sekolah (Arifin dkk, 2016). sejalan dengan hal tersebut (mendikbud, 2018) juga menyebutkan bahwa MBS adalah salah satu basis manajemen pengelolaan sekolah yangmemberikan otonomi lebih besar kepada sekolah dan mendorong pengambilan keputusan bersama secarapartisipatif darisemua warga sekolahdanmasyarakat di sekitarnya dalam upaya mengembangkan dan meningkatkan mutu pendidikan. Model manajemen demikian ditujukan untuk memberikan kemandirian kepada sekolah serta meningkatkan mutu pendidikan Berdasarkan uraian yang di sampaikan oleh ahli di atas menunjukkan secara garis besar bahwa tujuan diadakannya MBS adalah untuk peningkatan mutu pendidikan di Indonesia.

MBS pertama kali di mulai di negara Amerika dan di Indonesia mulai di gaungkan pada tahun 2000.Pendidikan di Indonesia sebelum adanya MBS adalah manajemen pendidikan yang terpusat, namun dengan di berlakukannya MBS maka terjadi perubahan pada manajemen 
pendidikan. Banyaknya bukti empirik tentang lemahnya pola lama manajemen pendidikan nasional dan digulirkannnya otonomi daerah, membawa konsekuensi pada perubahan manajemen sekolah. Sebuah konsekuensi logis untuk dilakukan penyesuaian manajemen pengelolaan sekolah dari pola lama menuju pola baru. Pola baru manajemen pendidikan juga dibutuhkan untuk mengantisipasi perkembangan zaman yang lebih bernuansa otonomi dan demokratis. Dimensi perubahan dapat dilihat Pada Tabel 1 yang di nyatakan oleh Departemen Pendidikan Nasional pada tahun 2001 (Depdikbud, 2018).

Tabel 1 Dimensi Perubahan Pola Manajemen Pendidikan

\begin{tabular}{|c|c|c|}
\hline Pola Lama & Menuju & Pola Baru \\
\hline Subordinasi & $\cdots>$ & Otonom \\
\hline Pengambilan keputusan terpusat & $\cdots$ & Pengambilan keputusan partisipatif \\
\hline Ruang gerak kaku & $\cdots>$ & Ruang gerak luwes \\
\hline Pendekatan birokratik & $\cdots>$ & Pendekatan profesional \\
\hline Sentralistik & $\cdots$ & Desentralistik \\
\hline Diatur & $\cdots>$ & Motivasi diri \\
\hline Overregulasi & $-\cdots$ & Deregulasi \\
\hline Mengontrol & $\ldots$ & Mempengaruhi \\
\hline Mengarahkan & $\cdots>$ & Memfasilitasi \\
\hline Menghindari resiko & $\ldots>$ & Mengelola resiko \\
\hline Gunakan uang semuanya & $\cdots$ & Gunakan uang seefisien mungkin \\
\hline Individual yang cerdas & $\ldots$ & Teamwork yang cerdas \\
\hline Informasi terpribadi & $\cdots$ & Informasi terbagi \\
\hline Pendelegasian & $\cdots$ & Pemberdayaan \\
\hline Organisasi hierarkis & $\cdots>$ & Organisasi datar \\
\hline
\end{tabular}

Depdikbud (2018)

\section{Karakteristik Manajemen Berbasis Sekolah (MBS)}

Nurkholis (2009:56) menyebutkan jika MBS ingin berhasil, maka terlebih dahulu harus mengikuti kriteria yang ditetapkan.berikut ada 8 kriteria yang disebutkan, yaitu:

a. Sekolah dengan MBS memiliki misi atau cita-cita menjalankan sekolah untuk mewakili sekelompok harapan bersama, keyakinan dan nilai-nilai sekolah, membimbing warga sekolah di dalam aktivitas pendidikan dan memberi arah kerja. Misi ini mempunyai pengaruh yang besar terhadap fungsi dan efektivitas sekolah, karena dengan misi ini warga sekolah dapat mengembangkan budaya organisasi sekolah yang tepat, membangun komitmen yang tinggi terhadap sekolah, dan mempunyai insiatif untuk memberikan tingkat layanan pendidikan yang lebih baik.

b. Aktivitas pendidikan dijalankan berdasarkan karakteristik kebutuhan dan situasi sekolah. Hakikat aktivitas sangat penting bagi sekolah untuk meningkatkan kualitas pendidikan, karena secara tidak langsung memperkenalkan perubahan manajemen sekolah dari menajemen kontrol eksternal menjadi model berbasis sekolah.

c. Terjadinya proses perubahan strategi manajemen yang menyangkut hakikat manusia, organisasi sekolah, gaya pengambilan keputusan, gaya kepemimpinan, penggunaan kekuasaan, dan keterampilan-keterampilan manajemen. Oleh karena itu dalam konteks pelaksanaan MBS, perubahan strategi manajemen lebih memandang pada apek pengembangan yang tepat dan relevan dengan kebutuhan sekolah. 
d. Keleluasaan dan kewenangan dalam pengelolaan sumber daya yang efektif untuk mencapai tujuan pen-didikan, guna memecahkan masalah-masalah pendidikan yang dihadapi, baik tenaga kependidikan, keuangan dan sebagainya.

e. MBS menuntut peran aktif sekolah, adiministrator sekolah, guru, orang tua, dan pihakpihak yang terkait dengan pendidikan di sekolah. Dengan MBS sekolah dapat mengembangkan siswa dan guru sesuai dengan karakteristik sekolah masing-masing. Dalam konteks ini, sekolah berperan mengembangkan insiatif, memecahkan masalah, dan mengeksplorasi semua kemungkinan untuk memfasilitasi efektivitas pembelajaran. Demikian halnya dengan unsur-unsur lain seperti guru, orang tua, komite sekolah, administrator sekolah, dinas pendidikan, dan sebagainya sesuai dengan perannya masingmasing.

f. MBS menekankan hubungan antar manusia yang cenderung terbuka, bekerja sama, semangat tim, dan komitmen yang saling menguntungkan. Oleh karena itu, iklmi orgnanisasi cenderung mengarah ke tipe komitmen sehingga efektivitas sekolah dapat tercapai.

g. Peran administrator sangat penting dalam kerangka MBS, termasuk di dalamnya kualitas yang dimiliki administrator.

h. Dalam MBS, efektivitas sekolah dinilai menurut indikator multitingkat dan multisegi. Penilaian tentang efektivitas sekolah harus mencakup proses pembelajaran dan metode untuk membantu kemajuan sekolah. Oleh karena itu, penilaian efektivitas sekolah hatus memperhatikan multi tingkat, yaitu pada tingkat sekolah, kelompok, dan individu, serta indikator multi segi yaitu input, proses dan output sekolah serta perkembangan akademik siswa.

\section{Peranan Manajemen Berbasis Sekolah (MBS)}

Untuk bisa berperan dengan baik dan efektif, maka adal langkah-langkah atau strategi yang bisa digunakan untuk menjalankan MBS. Strategi manajemen pendidikan berbasis sekolah, akan mempengaruhi efektivitas pencapayan tujuan pendidikan. Strategi adalah serangkayan rencana yang sistematis dan terstruktur, dalam pelaksanaanya secara menyeluruh dan jangka panjang dalam pencapaian tujuan model MBS.Veithzal \& Murni (2010) menyebutkan bahwa strategi pelaksanaan MBS dalam konsep peningkatan mutu, maka harus melakukan tahapan kegiatan sebagi berikut.

a. Menyusun basis data frofil sekolah yang tepat, akurat, valid, dan secara bertahap mengenai berbagai aspek akademik, administratif (peserta didik, guru, staf), dan keuangan.

b. Melakukan self assesment (evaluasi diri) guna menganalisis keuangan dan menganalisis sumber daya sekolah, kinerja pelaksanaan organisasi dan mencapayan kurikulum dan hasil yang dicapai peserta didik berkaitan dengan aspek-aspek intelektual dan keterampilan, maupun aspek lainnya.

c. Sekolah harus membaca keperluan sekolah dan meruskan visi, misi, dan tujuan dalam rangka penyajian pendidikan yang bermutu.

d. Berangkat dari visi, misi, dan tujuan membentuk pendidikan yang bermutu tersebut maka sekolah dan masyarakat seiring seirama merencanakan dan menyusun program jangka panjang atau jangka pendek (tahunan termasuk anggaran di dalamnya).

e. Sekolah harus membuat pemetaan serangkayan rencanaan prioritas dan pengembangan jangka panjang. Perencanaan jangka panjang dinyatakan sebagi strategi harus menempatkan pada tujuan pelaksanaan yang penting. 
f. Melaksanakan monitoring dan evaluasi untuk memastikan apakah rencana yang telah direncankan dapat berjalan secara semestinya. Dengan fokus dalam pembentukan mutu peserta didik, maka pelaksanaan monitoring dan evaluasi harus memenuhi kebutuhan peserta didik.

Strategi yang diungkapkan di atas dapat kita lihat pada hasil penerapan artikel-artikel penelitian yang sudah publish di jurnal nasional, seperti penelitian dari Arfin dkk (2016) yang melakukan penerapan MBS pada Sekolah Menengah Atas (SMA) dan penelitian Nasaruddin (2018) yang dilakukan pada tingkat Sekolah Dasar (SD). hasil-hasil penelitian menunjukkan adanya efektifitas dari penerapan MBS yang dilakukan, efektifitas ini mengindikasikan hasil ke arah peningkatan mutu pendidikan baik jenjang sekolah dasar ataupun sekolah menengah.

Dari beberapa penelitian tentang MBS dapat di simpulkan masih ada hambatan dalam prosesnya, sperti:

a) Tidak berminat untuk terlibat. Sebagian orang tidak menginginkan kerja tambahan selain pekerjan yang sedang mereka lakukan, banyak persepsi bahwa kegiatan yang dilakukan hanya menambah beban.

b) Tidak Efisien. Pengambil keputusan yang diambil dengan partisipasi ada kalanya menimbulkan frustasi dibandingkan dengan cara-cara yang otokratis. Stakeholder dan masyarakat terkait harus fokus pada tugas dan fungsi. 3)

c) Pikiran Kelompok.dengan adanya sering bersama, para masyarakat semakin kompak. Di satu sisi, berdampak positif dikarenakan saling mendukung. Di sisi yang lain, akan menyebabkan terlalu banyak kompromi terhadap keputusan yang dibuat.

d) Memerlukan Pelatihan. Pihak-pihak yang berkepentingan tidak atau belum berpengalam menerapkan model yang rumit dan partisifasif.

e) Kebingungan Atas Peran dan Tanggung Jawab Baru. Pihak-pihak belum terbiasa dengan suasana kerja baru. Penerpan MBS memperbaharui peran dan tanggung jawab pihakpihak yang berkepentingan.

f) Kesulitan Koordinasi. Dikala penerapan model yang rumit dan kagiatan yang beragam mewajibkan kordinasi yang baik. Tanpa kordinasi, kegiatan akan berjalan masing-masing bisa jadi menjauh dari tujuan sekolah yang sudah direncanakan.

Hal-hal hambatan tersebut harus di antisipasi atau lebih diperhatikan, dengan cara bisa mensosialisasikan program MBS dengan lebih kontinu, komprehensif dan berkesinambungan juga melakukan pelatihan-pelatihan terhadap warga sekolah.

\section{Daftar Pustaka}

Arifin,I.S., Bisri,H., Ichsan, M. 2016. MODEL MANAJEMEN BERBASIS SEKOLAH DALAM PENINGKATAN MUTU SEKOLAH MENENGAH KEJURUAN. Ta'dibi ISSN 2442-4994 Volume 5 Nomor 2, Oktober 2016.

Asmara, AS \& Ardiyanti, Y. 2019. Pengelolaan Pendidikan Untuk Guru dan Calon Guru. KArawang. FBIS PUBLISHING. ISBN: 978-602-0703-32-9.

Depdikbud. 2018. MANAJEMEN BERBASIS SEKOLAH (MBS) SEKOLAH MENENGAH ATAS. Jakarta. DIREKTORAT PEMBINAAN SMA DITJEN PENDIDIKAN DASAR DAN MENENGAH.

Dolong, H.M.J. 2018. KARAKTERISTIK MANAJEMEN PENDIDIKAN BERBASIS SEKOLAH. Journal UIN ALAUDIN. Volume VII, Nomor 1, Januari - Juni 2018.

Mutohar, P. M. 2013. Manajemen Mutu Sekolah, Jogjakarta: Ar-Ruzz Media. 
Nasaruddin. 2018. Pelaksanaan Manajemen Berbasis Sekolah (MBS) pada SD Inpres Bira 1 Kota Makasar. IKAP PGSD: Jurnal Ilmiah Ilmu Kependidikan Vol,2. No,2. Tahun 2018 e-ISSN: 2597-4440 dan p-ISSN: 2597-4424. 